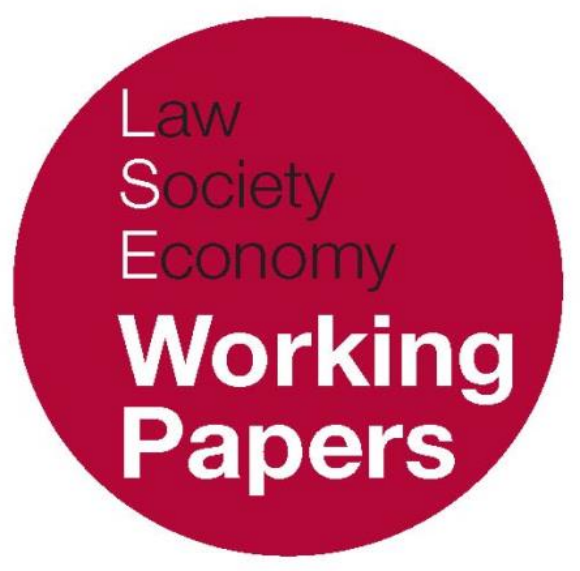

\title{
Contours and Conflicts in Tax Design: Principles and International Practice
}

\author{
Parthasarathi Shome
}

LSE Law, Society and Economy Working Papers 11/2018 London School of Economics and Political Science

\section{Law Department}

This paper can be downloaded without charge from LSE Law, Society and Economy Working Papers at: www.lse.ac.uk/collections/law/wps/wps.htm and the Social Sciences Research Network electronic library at: http://ssrn.com/abstract $=3199902$.

(C) Parthasarathi Shome. Users may download and/or print one copy to facilitate their private study or for non-commercial research. Users may not engage in further distribution of this material or use it for any profit-making activities or any other form of commercial gain. 


\title{
Contours and Conflicts in Tax Design: Principles and International Practice
}

\author{
Parthasarathi Shome *
}

\begin{abstract}
Tax design is said to be based on certain principles comprising efficiency of resource allocation despite taxation's distortionary effects, maintenance or encouragement of equity among taxpayers, and assisting in macro-economic stabilisation. Other safeguards are a tax system's revenue productivity, clarity of taxation law, ease of tax compliance, and facilitation of tax administration. Common experience reveals, however, that no tax structure complies with these criteria all at once, for the principles tend to conflict with one another.

The term reform is variously used by authors and across tax professions-economists, legal experts, accountants, administrators - their emphasis varying significantly. Bridging these gaps remains a crucial challenge. Empirical evidence also suggests that when a new administration takes over, it puts its own stamp on tax policy, egged on by lobbyists who were adversely affected in earlier change cycles. And, with the internationalisation of taxation, a country's tax structure gets affected by developments in political or trading blocs.

With this background, this paper points towards vacillations and drifts in the way tax changes occur. Consumption taxes (VAT/GST), production taxes such as excises, environment taxes, and user charges, as well as direct taxes including income and wealth taxes, and their component taxes on dividends, capital gains, cash-flow, presumptive bases, minimum tax payments, and emerging factors in international taxation, are taken up.

In conclusion, the effects of taxes go beyond narrow economic aspects. Legal, accountancy or administrative aspects carry important implications. The glass wall between tax economics and tax law or accountancy, and between tax economics and tax administration, if removed, would generate an awareness with beneficial crossover effects. Then tax reform can be discussed on the same plane and be implemented with comparable understandings.
\end{abstract}

\footnotetext{
* Visiting Fellow, London School of Economics and Political Science, 2017-18. Chairman, International Tax Research and Analysis Foundation, Bangalore (partho.shome@itraf.org), www.itraf.org and www.parthoshome.com. The paper was presented in the LSE Taxation series at the Faculty of Law on February 19, 2018. It was revised on April 27, 2018.
} 


\section{INTRODUCTION}

Tax design should have theoretical underpinnings in the form of principles of taxation comprising efficiency of resource allocation despite taxation's distortionary effects, its ramifications on inequity, and its potential in economic stabilisation. Nevertheless it should bear in mind broader perspectives of revenue productivity, clarity of taxation law, ease of tax compliance, and facilitation of tax administration ${ }^{1}$. Most of these principles are well-known but they become important or recede to insignificance with the vagaries of time or of particular situations.

When economies function well, equity is of less concern. But when the economy is foundering, progressivity in taxation protects the less well-off. Progressive tax rates also stabilise the economy from unwanted or unexpected fluctuations. Blanchard et $\mathrm{al}^{2}$ brought together a collection of papers at a conference at the IMF that comprehensively discussed crisis and post-crisis policies to stabilise fluctuations. Roxan ${ }^{3}$ and others have, in this context, pointed towards the limits of globalisation and their ramifications for taxation.

Another aspect of tax design that is crucial is how a tax affects the efficiency of resource allocation by attempting to minimise tax incentives that distort relative prices across sectors and result in erroneous signals for production-away from consumer preferences. A seminal early treatise on the distortions and deadweight loss of taxation itself was by Harberger ${ }^{4}$.

Apart from those three principles, any country authority would be interested in additional characteristics in a tax system. For example, a buoyant tax structure that has a built-in ability to be revenue productive during both affluent years through the income tax and during deflation through a VAT or GST is warranted ${ }^{5}$. Further, despite good intentions of the tax designers, if the tax law is cumbersome and hard of interpretation, the tax system loses its sharpness and ends in litigation and, the worse is the law, the longer is the litigation process likely to be ${ }^{6}$. Thus, simplicity and the associated ease of taxpayer compliance have increasingly come to be recognised as an important tenet of tax design, the "ease of paying taxes" being included as a component of the World Bank's cross-country "ease of doing

\footnotetext{
${ }^{1}$ Baker, Philip and Piston, Pasquale. 2015. 'The Practical Protection of Taxpayers' Fundamental Rights,' General Report, International Fiscal Association, 2015 Basel Congress, Volume 100B; Shome, Parthasarathi. 2014. Taxation Principles and Applications: A Compendium, Lexis Nexis, New Delhi. See various chapters on VAT and GST in an international context, Section I.2.

${ }^{2}$ Blanchard, Olivier J., David Romer, Michael Spence, and Joseph E. Stiglitz ed. 2011. In the Wake of the Crisis: Leading Economists Reassess Economic Policy, International Monetary Fund, M.I.T Press, Cambridge, Massachusetts.

${ }^{3}$ Roxan, Ian. 2012. 'Limits to globalisation: some implications for taxation, tax policy, and the developing world,' LSE Law, Society and Economy Working Paper Series, 3/2012, Law Department, London School of Economics and Political Science, London, UK.

${ }^{4}$ Harberger, Arnold C. 1974. Taxation and Welfare, University of Chicago Press, Chicago. See also Shome. 2014. Section III.

${ }^{5}$ Shome. 2014. Section I.3.

${ }^{6}$ Butani, Mukesh. 2016. Tax Dispute Resolution - Challenges and Opportunities for India [Derived from Challenges of Indian Tax Administration], LexisNexis, New Delhi.
} 
business" index 7 . Last, and perhaps most important, are a tax administration's transparency, incorruptibility and impartial application of the law even as subordinate legislation or administrative rules that override legislative intent are minimised 8 .

\section{CONFLICTS AMONG PRINCIPLES}

It is not uncommon for various principles and objectives to conflict with one another with the outcome of reform becoming undecipherable or anomalous. An inefficient tax that can raise revenue in the short run could impinge upon economic growth and thus lead to revenue stagnation in the medium term. Indulgence in taxing capital gains appropriately would lead to inequity across income sources; yet adverse tax treatment of capital income could slow down capital accumulation and economic growth. It is this fear that had led to a long period of accommodation to the taxation of returns to capital of multi-national companies (MNCs). A collection of legal experts, economists and tax administrators has considered a list of related issues in Shome9. The flip side perception of tax administrations is that MNCs organise their tax matters to minimise tax payments globally through complex tax avoidance - separated from tax evasion-leading, in the extreme case, for some tax administrations to attempt to stem it through retrospective taxation. Of course, a well-worn method to stem both sides of the problem-tax depletion and double taxation - has been the painstakingly slow approach of double taxation avoidance agreements (DTAAs), a recent evolution and analysis having been carried out by Baistrocchi ${ }^{10}$.

An investor can use a business model that would guide him to decide how much investment he should make in a given risky environment. This of course would be determined by the extent of his aversion, neutrality or preference towards risk. Uncertainty removes the possibility for existence of such a dependable business model. The investor makes a decision to invest reflecting, from his standpoint, a known tax risk that reflects his attitude towards risk. If, however, say after five years of his investment decision, the government declares that the tax law has been now changed from five years prior to the present day, the basis of that investment crumbles. It is as if informing him today in time $t$ that the law in time $t-5$ was actually quite different from what had been written down as law in $t-5$. This manner of

\footnotetext{
7 World Bank. 2016. Doing Business - 2017: Equal Opportunity for All, 25 th October.

8 Shome, Parthasarathi. 2015. Tax Administration Reform in India: Spirit, Purpose and Empowerment (Volume 4),

Report of the Tax Administration Reform Commission (TARC), Ministry of Finance, Government of India, New Delhi.

${ }_{9}$ Shome, Parthasarathi ed. 2016. Base Erosion and Profit Shifting (BEPS): The Global Taxation Agenda, International Tax Research and Analysis Foundation (ITRAF), Wolters Kluwer, New Delhi.

${ }_{10}$ Baistrocchi, Eduardo ed. 2017. A Global Analysis of Tax Treaty Disputes, Cambridge University Press, London.
} 
retrospectivity in taxation becomes untenable for business decision making. Yet certain tax jurisdictions have tended to use this unjustifiable legal device with the objective of capturing revenue already lost through legal interpretation of the law.

MNCs have explicably complained that retrospective legislation leads to an uncertain - as opposed to merely risky-environment thus leading them to scale back investments from such jurisdictions. Reflecting the high mobility of international capital, such withdrawal can be brisk. Lower investment leads to lower growth and, therefore, to lower tax revenue collection. And the deleterious growth effects of taxation could be near permanent, rather than merely transitory. ${ }^{11}$

\section{DOES TAX REFORM LAST}

How often, how far, and across what expanse of geographical reach can tax reform be said to have achieved success? Relatively little. Why? First, the term itself is variously used by authors, for example, Bernardi, Fraschini and Shome, Chen and Mintz, Focanti et al, Gimenez and Rodriguez, Alm et al, or Ruiz et al ${ }^{12}$ to name a few. Second, the concept of tax reform varies across tax professions. Economists tend to emphasise the efficiency criterion, remaining critical of a structure that has too many tax incentives. Some economists believe that achieving equity using expenditure policies is superior to a structure that uses taxation. Legal experts tend to focus on the sharpness or clarity of a law and, if not, they take as a worthy challenge, intelligent interpretation of the law, to be resolved by the judiciary. And a tax administrator's best tax structure is the most revenue productive. It is almost as if there is a glass wall between the tax economist and the legal expert and, again, between the tax economist and the tax administrator. Differences between a legal expert and a tax administrator in the interpretation of the law also emerge, reflecting fundamental differences in professional perceptions. Bridging these perceptible gaps perhaps remains a crucial challenge to the larger taxation profession ${ }^{13}$.

\footnotetext{
${ }^{11}$ And whether tax payments by MNCs on the whole—as opposed to a few service oriented ones that were difficult to be pinned down regarding the existence of their permanent establishments in any tax jurisdiction - have been low in terms of their profits has been questioned by some including Shome ed. 2016. in the context, specifically, of India.

12 Bernardi, L., Fraschini, A. and Shome, P. ed. 2006. Tax Systems and Tax Reforms in South and East Asia, Routledge, Oxford; Mintz, Jack and Chen, Duanjie. 2011. 'Federal-Provincial Business Tax Reforms: A Growth Agenda with Competitive Rates and a Neutral Treatment of Business Activities,' SPP Research Papers, The School of Public Policy, University of Calgary, Vol 4(1); Focanti, Diego, Hallerberg, Mark, and Scartascini, Carlos. 2013. Tax Reforms in Latin America in an Era of Democracy, IDB Working Paper Series, No. IDB-WP-457; Gimenez, EL and Rodriguez, M. 2016. 'Optimality of relaxing revenue-neutral restrictions in green tax reforms', Governance and Economics Research Network (GEN), GEN Working Paper A 2016 - 5; Alm, James, Sheffrin, Steven M. 2016. 'What Drives State Tax Reforms?', Public Finance Review, Vol 45(4), pp: 443-457; Ruiz, SVl, Peralta-Alva, A. and Puy, D. 2017. Macroecoenomic and Distributional Effects of Personal Income Tax Reforms: A Heterogenous Agent Model Approach for the US, IMF Working Paper, WP/17/192.

${ }^{13}$ Shome, Parthasarathi ed. 2013. Indian Tax Administration: A Dialogue, Orient Blackswan, New Delhi.
} 
Even if it is argued that those differences are not terribly important, a source of the ephemeral nature of tax reform emerges from empirical evidence which suggests that, after about five years of undertaking reform, country authorities face new challenges to the edifice that begins to crack. First, those who are adversely affected, even if marginally, begin to lobby, often steadily and strongly, for reinstatement of their privileges, usually for sector specific tax incentives, tax holidays, accelerated depreciation, lowered VAT rates for individual commodity classifications and so on. Thus, those who complain rightly about the adverse effects on them of retrospective taxation, now take on the role of the hungry bird as soon as the situation permits.

Second, in most democracies there is likely to be a change in government in four, five or six years; and the new administration likes to put its own stamp on public policy including, or in particular, tax policy. Relatedly, third, the term 'tax reform' probably possesses the worst interpretation of the second word in modern professional usage. Any change is termed reform and successive governments attempt to rapidly change what their predecessors have done. Thus, by a mere check of definition or consistency, these changes can hardly be called reform. In fact, there is constant justification made for 'change' for which tax administrations have tended to set up full and comprehensive departments, rendering a rather amusing interpretation that tax policy or tax administration reform may never achieve a stable equilibrium.

And last but not least, fourth, with the ever longer global reach and internationalisation of taxation, a country's tax structure gets affected by multilateral movements in international taxation as well as by changes in political or trading blocs. Thus the life of a global trend in tax reform can be cut short through blowing international winds that fail to adhere to modern tenets of taxation.

\section{TAX STRUCTURE}

\section{i. WHY TAX EXPENDITURE AS WELL AS INCOME}

An economy's overall supply equals its demand after accommodating for its exports and imports. The supply of output may be expressed as the incomes the production generates comprising the economy's wage income, capital income, and land income.

Using the incomes, economic agents make demands in the market for consumption and investment by both individuals and the public sector. This supplydemand mirror image is usually referred to as the national income identity. ${ }^{14}$

The question to ponder is, if both sides are essentially the same thing, what is the rationale, need or justification for taxing both the demand and supply side of

${ }^{14}$ See Lipsey, Richard and Steiner, Peter. 1975. Economics, Harper and Brothers, New York; and Dernburg, Thomas F. 1960. Macroeconomics, McGraw-Hill, New York, for early expositions. 
the same economy? Would not the tax structure be simpler if only the demand or the supply side were taxed. ${ }^{15}$ Indeed, as a country develops and its tax system becomes more mature, it becomes apparent that its overall tax structure also becomes more complex. Is there no reprieve from this?

There are reasons for this "double" taxation, however, for there are pros and cons associated with taxing consumption as well as income. Among the advantages of consumption taxation such as with a VAT or GST, the first is the exemption of savings. By contrast, investment could be visualised as being taxed under the income tax, once as income and, second, on the returns from income. Second, a consumption tax could be designed with progressive elements. Its disadvantages comprise, first, its perception as a payroll tax from a lifetime perspective excluding bequests and inheritances and, therefore, causing undue burdens on wage earners. Second, income tax relies on the comprehensive Haig-Simons definition of income as accretion of power to consume and, therefore, the proper basis for equity in taxation. Nevertheless, many developing countries depend heavily on the VAT as a revenue earner since it has been essentially a domestic tax, easier to administer and collect. Similarly many developing countries collect tax through customs duties on imports at the border. Thus VAT/GST plus customs duties tend to comprise a significantly higher share of their revenues. With economic development, income taxes claim growing and higher shares.

Thus, though on a purely conceptual basis, taxing both the income and expenditure sides of the macro-economic identity may be interpreted as taxing both supply and demand, nevertheless, in practice, it has not stopped tax authorities from imposing taxation on both. Thus what is conceptually clean may not always comprise the limits of the applied tax base. In the ultimate analysis, the practice of taxation reflects a combination of what is implemented with the intermittent incorporation, in the form of tax reform, of concepts developed through the progress of tax theory. Thus, it occurred that both income and expenditure were used as revenue bases as the tax instrument began to be applied increasingly widely.

\section{ii. DOMESTIC CONSUMPTION AND PRODUCTION TAXES}

Value added tax (VAT) or goods and services tax (GST): The internationally accepted prevailing premise is that the best consumption tax from an efficiency point of view is a single or two-rated VAT or GST that credits all input taxes against all output taxes to be transferred to the exchequer. This obviously weeds out any embedding of prior-paid taxes in a product price, thus avoiding cascading or "tax on tax". The philosophy of a VAT could be viewed as preferring a simple structure

15 Thus, Uruguay decided to replace its income tax altogether with a broad-based VAT. Indeed, many Latin American countries, for their stage of growth, have faced challenges to levy and collect from an ample income tax. 
with a single or few rates that are charged directly at production and distribution points ${ }^{16}$.

Nevertheless, there is a lingering issue with this for, reflecting the theory of "optimal taxation", in order to eliminate economic distortions and "deadweight loss" associated with commodity taxation, the tax rate for every commodity should be ideally distinguished from another, pegging it at the inverse of its elasticity of demand. To explain simply, an inelastic good whose demand changes little with price movements can bear a higher tax rate since its demand would not change much with a rate increase in its tax (a price); hence the deadweight loss associated with the tax change would be lower. Zee ${ }^{17}$ analyses the associated algorithms. Contrary is the case with an elastic commodity whose tax rate should therefore be lower.

In the amalgam of "indirect tax" theory, the VAT seems to have won out perhaps reflecting its easier collection mechanism using the debit-credit principle applied using output and input invoices. This is despite the fact that there is no country that has only one or two VAT rates; they have many rates that vary according to the type of product or product use. Indeed many countries have books full of VAT rates. India's new GST introduced on July 1, 2017, suffers similarly from a large number of rates. It is a fiscal federal VAT comprising both the central and state governments. At the level of states, it earlier had a VAT that had lower rates for capital goods-presumed inputs—even though the VAT paid on them would be credited out anyway. The same structure continues in the new GST.

The VAT base is usually diminished by exemptions (where output is not taxed so that input tax credit is not given); or zero rating (where output is not taxed, nevertheless input tax credit is given), and so on. VAT has also developed complex administration mechanisms such as reverse charge, presumptive taxation such as on cross-border reinsurance services, interpretation between goods and services for composite products such as set-top boxes to name just a few.

Reflecting this experience with the VAT that has had to deal with a considerable degree of complexity, it is difficult to surmise why the tenets of optimal taxation following the inverse elasticity rule unabashedly lost out to the VAT. One explanation could be that a tax reflecting inverse elasticity of demand could lead to more inequity than the VAT if it were true that goods consumed by the less welloff are more inelastic since their consumers cannot easily alter their meagre consumption baskets which, in turn, would imply higher tax rates as per optimum taxation rules. Whereas, as we move towards luxury goods, the elasticity of demand would tend to increase, and thus the tax rate would decrease. However, Atkinson and Stiglitz have shown that it is not impossible to build in an equity component in an optimal tax system. And it is not as though the VAT in general is far more equitable for it is well known that a VAT, being a consumption tax that exempts

16 Shome. 2014. Section IV.

${ }^{17}$ Zee, Howell H. 1995. “Tax Cascading: Concept and Measurement," in P. Shome ed., Tax Policy Handbook, at III. International Monetary Fund, Washington, D.C. 
savings, is bound to be somewhat inequitable as well. Thus the resounding victory of the VAT as widely practised over optimal taxes remains a bit of a mystery.

One thing is clear. Excise taxes are revenue productive. Excises on turnover are obviously revenue productive. They feature in most country annual budgets as discretionary measures for revenue. But the VAT too is depended on for revenue. In fact, a measure of the VAT's revenue productivity was observed in Latin America by this author and it has been referred to as the Shome VAT productivity index ${ }^{18}$. If the general VAT rate is $\mathrm{X} \%$, then if it is designed well, it should be able to yield $1 / 2 \mathrm{X} \%$ of GDP in revenue. Chile and New Zealand both had an 18\% VAT rate and collected approximately $9 \%$ of their GDP in VAT revenue on a secular basis during the 1990 's. Most countries achieve $1 / 3 \mathrm{X} \%$ of GDP or above without touching $1 / 2$ $\mathrm{X} \%$. Countries that linger below $1 / 3 \mathrm{X} \%$ comprise examples of poor VAT performance. In the UK, with a $17.5 \%$ VAT rate, VAT revenue hovers near $1 / 3$ $\mathrm{X} \%$ (or 6\%) of GDP. The open secret of achieving high VAT revenue productivity is to structure the VAT in such a way that most commodities are at the general rate, there are not too many lower rates, exemptions are few, zero rated items are fewso that most goods and services are covered under the VAT-and tax administration is reliable so that VAT compliance is good and, last but not least, the taxpayer base is ample and can be steadily expanded.

VAT rates are supposed to be few. However, there is the prevalence of demerit goods such as tobacco and alcohol for domestic consumption, luxuries such as furs and yachts, and non-renewable resources such as the array or petroleum products and aviation fuel that, by convention, are accepted to be subjected to higher rates of indirect taxation than the VAT rate. Thus, countries usually apply excises selectively on the turnover of alcoholic products, yachts and furs, and petroleum products on top of including them in the VAT base. This has the advantage of retaining information on their input use and input costs as in the case of all VATable products. The reality is that most countries have a higher number of commodities on which they impose VAT plus excises. The appropriate excise rate structure has moved around somewhat with little economic rationale. When they were mainly "specific" rates or taxed by quantity of output, it was felt for decades that they should be taxed on an "ad valorem" basis in order for the value of excise revenue not to suffer from inflation. When country after country moved accordingly, tax administrators mainly from multilateral organisations began to push for specific rates with ease of administration as the objective.

Environmental taxes and user charges: These taxes and charges also fall in this broad category. The former, termed "Pigouvian taxes", apply for environmental objectives ${ }^{19}$. The idea is to impose a tax that would redress environmental damage,

18 Modi, Arbind. 2009. Report of the Task Force on Goods and Services Tax, Thirteenth Finance Commission, Government of India, 15 th December, New Delhi. In a subcommittee report on the introduction of a GST in India on a revenue neutral basis with respect to taxes that would be abolished, Modi addresses it.

19 Pigou, A.C. 1932. The Economics of Welfare, 4th Edition. Macmillan and Co., London. 
or 'internalise' the negative 'external' effects of the activity. This would rightly bring up the private costs of an economic activity thus helping bring the private cost of the activity to equate the social cost it causes. Thus such taxes could be used to reduce pollution by earmarking the revenue for cleaning up the environment. The European Union has moved significantly forward in environmental tax design while the United States has walked away from an international agreement on environment termed the Paris Agreement. The matter of a global carbon tax has also re-emerged in the context of the G-20's development agenda though it has not taken hold.

In matters of road maintenance and the provision of selected public services, charging users according to the extent of use has proved to be efficient- the benefit principle-for example in Singapore. Common concerns include methods to adequately identify the user, measure the intensity of use, safeguard fairness, and develop a correct table of user charges.

\section{iii. INCOME AND WEALTH TAXES}

The definition of income during a period reflects development of the Schanz-HaigSimons comprehensive income concept ${ }^{20}$. It is the sum of the market value of rights exercised in consumption and the change in the value of property rights between the beginning and end of the period in question. Most countries fail to adhere to it. In practice, features that determine tax liability include the specification of taxable unit, taxable income or sources of income subject to tax, the tax schedule and tax preferences. The number of brackets, the treatment of particular types of income for example the taxability, or not, of second or more real property, allowable deductions, exemptions, tax credit, tax sparing, formulae to mitigate the effects of inflation, further embellish and differ across tax systems.

In this mix, tax economists search for rationale for the income tax structure. They test the post-tax distribution of income across income deciles against pre-tax incomes; they check the corporation income tax's "long run" ramification for capital returns and, thus, on capital accumulation; they conduct experiments on the realisation of government's objective to maximise social welfare using the income tax and, at the same time, the efficiency costs of the income tax on individual work effort, and root for such normative characteristics to get reflected in the tax design. Musgrave, Harberger, Krzyzaniak, and Mieszkowski conducted the seminal works. ${ }^{21}$

20 The inclusion of net wealth in the tax base lends the phrase 'comprehensive' to the definition. Simon, Henry Calvert. 1938. Personal Income Taxation: The Definition of Income as a Problem of Fiscal Policy, Chicago: University of Chicago Press.

${ }^{21}$ Musgrave, RA. 1953. 'General Equilibrium Aspects of Incidence Theory', American Economic Review, Vol 43, pp 504-17; Harberger, Arnold C. 1962. 'The Incidence of the Corporate Income Tax', Journal of Political Economy, Vol 46, pp 75-85; Krzyzaniak, Marian. 1967. 'The Long-Run Burden of General Tax on Profits in a Neo-classical World', Public Finance/Finances Publiques, Vol 22, No. 4, pp 472-91; Mieszkowski, PM. 1967. 'On the Theory of Tax Incidence', Journal of Political Economy, Vol 75, pp 250-62. Others who followed included Shome, Parthasarathi. 1978. 'The Incidence of the Corporation Tax in India: A General Equilibrium Analysis', Oxford Economic Papers, Vol 30 (1), pp 64-73, reproduced in Shome. 2014. Section II.1; Shome, Parthasarathi. 1981. 'The General Equilibrium Model Theory and Concepts of Tax Incidence in the Presence of Third or More Factors', Public Finance, Vol 36(1), pp 22-38, reproduced in Shome. 2014. Section II.3; Shoven, John B, and John Whalley. 1972. 'A General Equilibrium Calculation of the Effects 
Nevertheless cross-country variation in income tax structure is significant, beginning from whether the individual income tax should have a global base or a country specific - scheduler - rate structure; and whether the corporate income tax should be based in the source country of income, or based on the residence country of the capital whose income is being taxed. This reflects fundamental and continuing differences across modern economies, and within the same economy over time, in their perceptions of fairness, adverse efficiency costs and, finally, on what the role of government should be in society and how much financing it would need for that role.

Design issues: While progressivity is generally accepted as a favourable feature to achieve equity, its definition varies. Thus, one measure, focusing on the distribution of taxes, could yield high progressivity as long as all taxes fall on a few, say the richest decile of taxpayers, even if the overall tax burden is low, say 1 percent to 1.5 percent of GDP as was common in the 1990's Latin America ${ }^{22}$. Another measure, focusing on after-tax distribution of income, may conclude that the same tax system reflects low progressivity. These differences assume great importance in prevalent income and wealth distribution patterns as wealth concentration across the globe narrows down on a few individuals.

While taxing comprehensive income may be the goal, its determination remains complex. For a business or corporation, the correct valuation of assets and liabilities through appropriate adjustment for inflation, income on accrual or cash basis, the length of time for which a loss may be carried forward or backward-so that risk taking firms are not overly penalised compared to risk averse firmsdepreciation rules-straight line, declining balance, accelerated depreciationinventory valuation — last in first out, first in first out, period average methods — or treatment of foreign currency assets with changing exchange rates, are but a few elements that comprise challenges for the taxpayer that, unless carefully interpreted and calculated, could lead to litigation with the tax authorities.

Integration of dividend income in individual and corporate income tax ${ }^{23}$ : More than a design issue, this is a conceptual area that has not yet been resolved. Dividends are a source of income that are taxed at the corporate level prior to distribution and then again after distribution as income in the hands of individuals. The case against this "double taxation" is that corporations have no independent ability to pay and are simply a pass-through for incomes to individuals. Conceptually this could be perceived in similar fashion to the collection of VAT through different stages of production and distribution; yet it is only the final consumer who

of Differential Taxation of Income from Capital in the US,' Journal of Public Economics, pp 281-321; and several others.

22 Shome. 2014. Sections I.5 and VI.3.

${ }^{23}$ Various authors have considered the details of the practices and the ideal direct tax structure in Shome ed. 1995. Tax Policy Handbook, International Monetary Fund, Washington, D.C., reproduced in Shome. 2014. Section V.3, a treatise that is in permanent use in various ministries of finance and tax administrations for reference and training. 
ultimately pays the entire tax, while the previous stages become merely collection points. In this sense the VAT is equivalent to a retail sales tax.

Yet there has been reticence on the part of adherents to the classical tax system to view corporations as conduits. Apprehension of revenue loss is a big reason for lack of full integration in classical systems such as India, the UK and the US. In any event, countries give at least partial tax relief at either the individual or corporate level. In India, for example, dividends are taxed through a dividend distribution tax (DDT) at a significantly lower rate prior to distribution by the corporate entity. Reflecting foreign tax credit issues, MNE's do not pay DDT but their corporate tax rate is higher than that of domestic companies.

Integration possesses another benefit. Interest payments are deductible by corporations (though ceilings may be worked into the tax structure to minimise thin capitalisation). However, dividend pay-out may not reduce the calculation of taxable profit. If so, the corporate tax structure would have a bias in favour of debt financing. A view does exist, however, that this favourable debt bias becomes less effective if profits are reinvested and the realisation of capital gains and, in turn, its taxation, are indefinitely postponed. In the final analysis, an easy approach to treat debt and equity financing in a neutral way is integration.

Taxation of capital gains: Ideally, capital gains on real property and financial assets should be taxed under comprehensive income. However due to both fear of adverse impact on investment as well as challenges of measuring accrued capital gains, governments tend to interpret capital gains as differently motivated. Thus they may be subject to lower tax rates or even exempted for finite periods. Differential taxation is also rationalised by viewing taxable income as a flow from capital sources, distinct from any changes to the value of those sources. When the tax schedule for capital gains is quite different from that of income, then the interpretation between income and capital gains assumes importance. Thus, if money made through exchange gains is not taxed until realised, should it be ordinary income or capital gains for tax purposes? Or if the capital is held for a randomly defined "short" or "long" term, should the tax rate differ-as in India?

Cash-flow tax: The corporate income tax has been criticised in that, for all its complexity in design, in practice it is not a tax on income as such but, rather, on some hybrid base that is residual of various exemptions and deductions, many of which are likely to be ad hoc. Therefore, some tax economists have recommended a simpler tax base that would approximate the cash-flow of a company. Despite the search for simplicity, immediately three variants of a cash-flow tax on corporations (CCFT) appeared, reflecting on a variety of interpretations of cash-flow itself.

The first variant is the $\mathrm{R}$ - or real—base CCFT in which the tax base is net real transactions (the difference between sales and purchases of real goods and services). As opposed to a corporate income tax (CIT), the RCCFT would allow immediate expensing of capital outlays but not the usual deduction for interest payments. Interest received would not be taxable either.

The second variant is the RF-or real plus financial—base CCFT that, in addition, includes in its tax base non-equity financial transactions (the difference 
between borrowing and lending). Interest and retirement of debt would be deductible, while borrowing and interest received would be taxable.

The third variant is the S-or shareholder-base CCFT, which would tax the net flow from the corporation to shareholders (dividends paid plus purchases of shares minus the issue of new shares); it would conform closely to the interpretation that the CCFT is a 'silent partnership' of the government in any investment.

The CCFT's advantages are primarily in the ease of practice and clarity of the tax base insofar as it does away with the problems of defining true economic depreciation, measuring capital gains, costing inventories, and accounting for inflation (although not in all variants of the tax). However, the CCFT suffers from possible tax avoidance and evasion that could be contained somewhat by selecting the more comprehensive RF-base over the R-base, thereby ensuring the inclusion of the financial sector in the tax base. On the other hand, an important advantage of the R-base, not shared by the RF-base, is non-deductibility of interest which eliminates incentives for debt over equity financing and obviates any need for inflation adjustment for the calculation of real interest. The S-base might be administratively simple but could result in a prohibitive tax rate reflecting its overtly narrow base.

Thus the choice among the three CCFT bases is challenging to make despite international discussions appearing from time to time over the matter. In particular, international considerations turn out to be important in any future implementation of CCFT because of unresolved treatment of foreign tax credit under a CCFT. To this author, the CCFT remains a theoretically attractive concept with accompanying practical difficulties whose time has not come in particular in the context of already existing concerns of tax base erosion and profit shifting (BEPS). ${ }^{24}$

Presumptive taxes: Philosophically, perhaps presumption is not a superior concept on which to base taxation; nevertheless presumptive taxes are administrative devices that are widely used for practical purposes in particular in developing countries. For example, under the VAT, often there is a generally applied presumptive taxation scheme-compounding-in which a threshold is defined below which a taxpayer is given the option not to have to maintain invoices and, instead, to pay tax at a low rate on a turnover base. It is not surprising that, usually, a concentration of taxpayers is found just below the threshold. A Latin American finance minister once lamented to this author that, "Doctor, in my country, there are many elephants hidden among the mice." 25

Arguments in favour of presumptive taxation are many including, for example, in the above case, the likelihood of losing potential taxpayers if strict VAT rules were applied to them. While the revenue per small taxpayer may not be high, there can be spillover effects that move them from the unorganised to the organised

${ }^{24}$ For further elaboration, see Shome, Parthasarathi and Schutte, Christian. 1993. "Cash-Flow Tax, Staff Papers, Vol. 40, No. 3, pp 638-662, International Monetary Fund, Washington D.C., reconsidered in Shome. 2014. Section V.3.

25 'Doctor' is a term used by many Latin Americans to convey a presumed learnedness. 
sector while protecting them from extortive tax officers. The cost of tax administration in terms of audit time is also reduced.

Presumptive structures could also be devised under the income tax, for example, requiring small taxpayers to submit certain annual figures of available input use such as electricity, cement or petroleum, based on which the tax administration could assess their net income by applying cost to profit ratios. However, the use of punitive presumptive tax rates to push small taxpayers into the general tax structure and regulations may backfire by causing taxpayers to recede underground.

Minimum income tax: A minimum tax could be perceived as an example or variant of presumptive taxation. The purpose of a minimum tax is to ensure that businesses or individuals with economic income do not regularly avoid paying tax on it. It becomes a method of generating revenue when a tax administration wants to ensure that all taxpayers pay at least a minimum even if they qualify for tax incentives that would reduce their tax liability to very low levels. It thus requires taxpayers to make minimum contributions to selected taxes. A minimum tax on business should reduce the inequity in income tax that could also arise due to differences in tax compliance across businesses. Political clout of large businesses to reduce tax impact on them is also contained. And, in an inflationary environment, gains made by debt-financed firms in reducing tax liability, are checked.

Forms of minimum taxes vary. Using turnover as the base provides certain advantages since turnover is the most easily measured financial variable for a business and most easily available to tax authorities. An assets based minimum tax has a theoretical appeal in that economic income could be expected to bear a systematic relationship to assets. It has to be designed carefully, however. One possibility is for its base to be gross business assets including cash and securities, receivables, inventories, land and other fixed assets at depreciated value, and intangible assets at amortised value. It is also possible to impose the tax on fixed assets — land, plant and equipment—but this discriminates against particular asset forms. Alternatively, it could be on net assets-gross assets net of debt-financed liabilities-but this does not remove the incentive to reduce the tax base through increased borrowing.

A gross assets based minimum tax has been used in Argentina, Ecuador, Mexico and Peru while India's minimum tax is book profits—variously defined over the years-based. Canada, Denmark, Norway and the US have minimum taxes based on a broader concept of income-with less deductions-for selected sectors with high capital use. Morocco has used a minimum tax based on turnover.

Mexico's minimum tax had a rate of 2 percent based on gross assets. The assets tax liability was designed to be roughly equivalent to a taxpayer's potential income tax liability. If the taxpayer is assumed to earn a 6 percent return on assets and the business income tax rate is 33 percent, then a 2 percent tax on assets is roughly equivalent. Taxpayers may credit their income tax liability against their assets tax liability.

In the US, tax is calculated on a redefined notion of business income. It is essentially computed by adding back certain tax preference items to income. 
Affected businesses - largely in exploration activities — are required to compute tax liabilities under the regular and alternative systems and pay the higher of the two.

India has a minimum alternate tax (MAT) based on book profits whose definition over the years has been amplified to make the tax base broader, and whose rate has also been increased. Interestingly the rate has moved up in consonance with the effective corporate income tax rate. Currently the MAT rate is 18.5 percent. And the MAT base now covers Special Economic Zones (SEZs) that otherwise receive profit linked incentives. Earlier attempts to move away from a book profits base to a gross assets base did not materialise. Even the current MAT is constantly under attack by companies.

Selected additional aspects of the contour of taxation such as the taxation of non-replaceable mineral resources, of the financial sector, fiscal federal considerations where different levels of government have separate taxing powers and revenue sharing responsibilities, and the entire area of how tax administrations in modern times continue to suffer from overreach on good taxpayers to the extent of impinging on investment and economic growth, can also be important. Essentially, emerging issues in income and related taxation remain ever-new and expanding. What emerges, as was hypothesised at the beginning, was its variety if not non-conformity. What may be perceived as conventional in one economy is perceived as distortionary or inequitable, and the dialogue continues. Sometimes even dialogue is truncated. The point to ponder is, what is, or what remains of, tax reform.

International taxation-advanced versus emerging economies: This area is by and large eschewed by tax economists-though there is no particular explanation as to why-and has fallen in the competence area of lawyers, accountants and administrators ${ }^{26}$. This is an area that is widely termed international taxation. One possible answer why tax economists, by and large, have not ventured into this area may lie in their derision to read reams of legal paper. Nevertheless it has become increasingly important that all tax professionals become familiar with the issues being addressed in this field ${ }^{27}$.

The Group of 20 Nations (G20) asked the Organisation of Economic Cooperation and Development (OECD) to suggest comprehensive measures to address egregious tax avoidance by multinational enterprises (MNEs) that are believed to structure their business arrangements through a process of tax base erosion by shifting profits (BEPS) among their parent companies, branches and subsidiaries across national boundaries. Essentially they locate profits in low tax jurisdictions and successfully minimise their total tax contribution in terms of their global profits. Though such operations are likely to be legal, advanced country tax administrations began to perceive such practices as unreflective of the intention of

${ }^{26}$ Shome, Parthasarathi ed. 2016. Insights into Evolving Issues of Taxation: Existing and Continuing Challenges, International Tax Research and Analysis Foundation (ITRAF), Wolters Kluwer, New Delhi.

${ }^{27}$ Rohtagi, Roy. 2005. Basic International Taxation: Principles, Vol. I, Richmond Law \& Tax. 
the law as the 2008 global financial, turned economic, crisis hit them hard in terms of significantly lower than trend revenue from the corporate income tax ${ }^{28}$.

When the BEPS steering group was formed, the OECD invited Brazil and India to participate thus moving away, for this purpose, from operating as a cluster of advanced economies. Even a decade back India had looked askance from the OECD as a rich country club and it required considerable effort to get India to participate in selected OECD deliberations. A short while before this, India's posture on international taxation had been strongly and publicly criticised by tax authorities of advanced economies in particular the US, compelling India to modify its position. In the end, by all accounts, India's role in BEPS turned out to be comprehensive as it made useful contributions to the 15 BEPS reports.

India, and several emerging economies, had steadfastly argued well before BEPS that tax revenue must justly accrue in source jurisdictions where value added was created in the international supply chain of a commodity or service. Advanced economies by and large ignored this stance, their position being, revenue should accrue where risk taking and management decisions were made and where capital resided. However, with the collapse in advanced economy revenue with the onset of the 2008 global crisis, they began to realise the potential revenue benefits of applying the source principle as India did. Recognising the validity of India's position, advanced economies pointed out, their disagreement lay less in India's philosophical stance than in the unpredictable implementation of Indian tax laws pertaining to international taxation as well as its practice of retrospective legislation that changed risk parameters of businesses ex-post.

Examining the array of BEPS recommendations, one may assess that there are good possibilities that they will be of benefit to India and other emerging economies. For example, Action 5 of BEPS highlights the so-called substance test, linking the accrual of intellectual property (IP) rights and associated income and the right of taxation thereof to where research and development (R\&D) take place, making jurisdictional taxability a more transparent phenomenon than before. This supports India's viewpoint to the extent that India is host to R\&D of MNEs. To achieve transparency, BEPS solidly fortifies exchange of information among tax administrations and raises it to a high pedestal, a matter that has also been pushed for by India while advanced economies have been historically reticent about it. At the same time, the OECD tends to neutralise its position inasmuch as BEPS Actions 8 to 10 go deeper into the relationship between risk taking and intangibles such as intellectual property (IP) to ensure that they are not dissociated from revenue rewards, thus tilting towards a position in favour of advanced economies.

Another concern where the Indian view has been vindicated is BEPS Action 6 on limiting treaty abuse and controlling treaty shopping by specifying a principal

28 Shome, Parthasarathi. 2013. "Political Economy of Debt Accumulation and Fiscal Adjustment in a Financial Crisis," in Deepak Mohanty ed. Monetary Policy, Sovereign Debt and Financial Stability: The New Trilemma, Cambridge University Press, India. 
purpose test for an MNE operation in a taxing jurisdiction ${ }^{29}$. This should assist India and emerging economies to receive a more rightful share of global MNE revenue. Nevertheless there were limits to what India and emerging economies could achieve. BEPS Action 1 could be safely viewed as not having fully achieved adequacy in the taxation of the digital economy, a matter that has remained of some concern to India where the digital economy has made a strong presence while escaping taxation and leading to intractable disputes. The BEPS' superficial assertion that already agreed upon taxation arrangements specified in the double taxation avoidance agreements (DTAAs) should be adhered to, limits the ability to tax the digital economy since most DTAAs did not anticipate and do not address this issue. It also reveals the continuation of strong influences of advanced economies in what position the OECD may finally take. Clearly the emerging problem of taxing bitcoins needs to be quickly guided lest an increasing number of countries begins to tax it unilaterally as is already beginning to occur.

MNEs have been productive in technology, in production and supply, and in raising living standards globally. Their tax performance should be segmented into good and bad performers. There are likely to be good taxpayers even among those who fall above the high threshold that BEPS Action 13 has stipulated for the detailed 3-step-master file, country-by-country $(\mathrm{CbC})$, local-reporting of their global operations. The authorities' expectation is that $\mathrm{CbC}$ coupled with information exchange would reduce disputes. Nevertheless, the importance of Advance Pricing Arrangements (APAs) whose speed has albeit been slow, cannot be minimised. A heavy-handed reporting system applied to all MNEs indiscriminately is detrimental to global productivity and growth. It is expectable that Action 13 would be scaled back in future deliberations reflecting that collapse in global growth was the motivator for the G20's BEPS initiative while revenue decline was only its offshoot. Ultimately, revenue at the cost of growth is unlikely to receive sympathetic ears from global policymakers, for lower growth would affect even revenue in the medium term.

\section{CONCLUDING REMARKS}

To conclude, the tax economist tends to view the theoretical underpinnings of taxation as the final analysis of taxation. They consider how the tatonnement process of price determination is vitiated by tax interventions which comprise many a form of price distortion; or how movement away from an equilibrium state by a factor of production must ensue when a partial tax is imposed on it. The corporation income tax is a manifestation of the latter which is levied only on capital use in the corporate

29 Roxan. 2002; and Shome, Parthasarathi. 2012. Expert Committee on General Anti-Avoidance Rules (GAAR), Government of India, New Delhi. 
sector and not on the non-corporate sector. And, at the end of such movements, the relative incomes of all factors of production - capital, labour, land-must equilibrate. No doubt these are important matters of investigation for they point to the direction of say, whether capital owners ultimately bear the corporate income tax or pass on the "incidence" - tax burden - to labour and/or land; or whether, as has been tracked, there is rapid flight of capital which is an extremely mobile factor of production.

What we saw in our discussion was that the ramifications of taxation do not end there. The ultimate incidence of taxation reflects all such aspects that go far beyond narrow "economic" aspects even though such legal, accountancy or administrative aspects may be considered somewhat overbearing. Nevertheless, the glass wall between tax economist and tax law or accountancy, and the glass wall between tax economist and tax administration must be removed with an awareness smoothly flowing from one to the other. Only then tax reform can be discussed on the same plane and implemented with comparable understandings. In an intricately inter-connected world of trade and investment and associated challenges of equitable revenue collection from productive enterprises and fair cross-country revenue distribution among nations, it is imperative for knowledge to break walls and cross boundaries. 